Depuis avril 1962, le C.E.D.A.O.M. édite la revue Afrique Contemporaine dont le no 5 est paru en février 1963 et qui tente de faire le point de tout ce qui paraît actuellement sur l'Afrique.

Dans sa forme actuelle, le C.E.D.A.O.M. qui est dirigé par R. Cornevin, Administrateur en Chef des Affaires d'outre-mer et auteur de nombreux ouvrages sur l'Afrique, constitue l'un des centres parmi les mieux outillés de Paris pour l'étude de l'Afrique Noire.

\title{
The International Congress of Orientalists
}

THE twenty-sixth International Congress of Orientalists will be held in New Delhi in 1964. It will be divided into ten principal sections, including Islamic Studies and African Studies. Some additional sub-sections may be organized, if necessary. Further information regarding the Congress may be obtained from the Secretary, Organizing Committee, XXVIth International Congress of Orientalists, Ministry of Scientific Research and Cultural Affairs, Government of India, New Delhi.

\section{'The African Historian'}

THE Historical Society of the University of Ife, Ibadan, published in March 1963 the first number of its journal The African Historian, a collection of essays on Yoruba history by members of the society. In a Foreword Dr. S. O. Biobaku emphasizes the importance of such local historical studies, from the results of which more general histories may be compiled.

\section{The British Institute of International and Comparative Law}

THrs Institute is now operating a Commonwealth Legal Advisory Service, under which information is supplied to the Legal Departments of countries interested, on developments in other parts of the Commonwealth which may be of particular concern to them in their programmes of law reform and legal organization. Membership, which includes a subscription to The International and Comparative Law Quarterly, costs $£ 4.4$ s. per annum.

The Institute has recently announced the publication of a Synoptic Table and Index of Reported Cases of the Penal Codes of East and Central Africa and the Gambia. This is part of a comprehensive Commentary on these Codes which is being prepared by Miss Hilary Cartwright and Mr. J. S. Read for publication at a later date. The Synoptic Table and Index is available to members of the British Institute at a reduced price of ros., plus 2s. postage. Inquiries and applications for membership should be made to the Director, The British Institute of International and Comparative Law, I Temple Gardens, Temple, London, E.C. 4 .

\section{Université d'Alger: Centre d'Etudes Sociologiques}

UN groupe de jeunes anthropologues s'est donné pour tâche d'aider à ressusciter la recherche sociologique en Algétie sur trois plans: création d'un centre de formation accélérée de sociologues, constitution d'une documentation organisée et cohérente sur la sociologie maghrébine, et réalisation d'un programme de recherches sur l'évolution des structures familiales en Algérie. Le cycle d'étude au Centre comporte plus de recherche personnelle que d'études livresques et les élèves sont partis enquêter pendant un an au profit d'une organisation de recherche appliquée; ils rédigent ensuite en six mois une thèse analogue à la thèse du I er Cycle de l'École Pratique des Hautes Études.

LeCentre de Documentation a pour but de recenser et surtout rendre accessible l'ensemble de la production ethnologique et sociologique sur le Maghreb, avant d'entreprendre, tâche 